九州大学学術情報リポジトリ

Kyushu University Institutional Repository

\title{
Production of Triploid Plants from Crosses between Diploid and Tetraploid Grapes (Vitis complex) through Immature Seed Culture and Subsequent Embryo Culture
}

Hiramatsu, Michikazu

Laboratory of Horticultural Science, Division of Agricultural Botany, Department of Plant Resources, Faculty of Agriculture, Kyushu University

Wakana, Akira

Laboratory of Horticultural Science, Division of Agricultural Botany, Department of Plant Resources, Faculty of Agriculture, Kyushu University

Park, Sung Min Laboratory of Horticultural Science, Division of Applied Plant Sciences, College of Agriculture and Life Scciences, Kangwon Nation University

Fukudome, Isao

Laboratory of Fruit Tree Science, University Farm, Faculty of Agriculture, Kyushu University

https://doi.org/10.5109/4525

出版情報：九州大学大学院農学研究院紀要. 48 (1/2)，pp.51-57，2003-10-01. Faculty of Agriculture, Kyushu University

バージョン :

権利関係 : 
J. Fac. Agr., Kyushu Univ., 48 (1·2), 51-57 (2003)

\title{
Production of Triploid Plants from Crosses between Diploid and Tetraploid Grapes (Vitis complex) through Immature Seed Culture and Subsequent Embryo Culture
}

\author{
Michikazu HIRAMATSU ${ }^{1+}$, Akira WAKANA ${ }^{1,2}$, \\ Sung Min PARK ${ }^{3}$ and Isao FUKUDOME ${ }^{4}$
}

\author{
'Laboratory of Horticultural Science, Division of Agricultural Botany, Department of \\ Plant Resources, Faculty of Agriculture, Kyushu University, \\ Fukuoka 812-8581, Japan \\ (Received June 30, 2003 and accepted July 15, 2003)
}

\begin{abstract}
To develop efficient embryo-rescue methods in breeding triploid grapes, a combination of immature seed culture and embryo culture, and embryo culture without the preceding culture of immature seeds were applied during different developmental stages of seeds from an interploid cross between tetraploid 'Red Pearl' and diploid 'Muscat Bailey A'. Embryos grew larger than $1 \mathrm{~mm}$ in their length after three months of the immature seed culture initiated between 24 and 56 days after pollination (DAP). Overall, the embryos through subsequent culture germinated and then grew into plantlets at the higher rates than did those cultured without the preceding immature seeds culture. The highest rate of seedling recovery was $31.5 \%$ per cultured seed when immature seeds were collected 52-56 DAP, though none of four growth regulators added separately to the medium of the preceding immature seed culture were effective for development of embryos cultured in the same period. Results from our present and recent studies on breeding triploid grapes indicated that a combination of immature seed culture and subsequent embryo culture initiated one to two weeks before veraison (the beginning of fruit-softening period) is the best method for efficient production of triploid grapes.
\end{abstract}

\section{INTRODUCTION}

Production of seedless fruits with high quality is one of the major objective in breeding table grapes. Hypo- and hypertetraploid from hybridization among tetraploid cultivars (Park et al., 1999b) and, especially, triploid from hybridization between diploid and tetraploid cultivars (Yamashita et al., 1993; Park et al., 2002; Wakana et al., 2002) have been indicated to be the alternative sources for new types of seedless grapes in addition to the stenospermocarpic grapes (Winkler et al., 1962; Einset and Pratt, 1975; Mullins et al., 1992).

Generally, in interploid crosses between diploid and tetraploid plants, seed abortion due to the endosperm degeneration during early embryogenesis is a serious problem for production of triploid plants (Esen and Soost, 1973; Sanford, 1983). In grapes, the germi-

${ }^{2}$ Laboratory of Fruit Tree Science, Division of Agricultural Ecology, Department of Plant Resources, Faculty of Agriculture, Kyushu University 811-2307.

${ }^{3}$ Laboratory of Horticultural Science, Division of Applied Plant Sciences, College of Agriculture and Life Sciences, Kangwon National University, Kangwondo 200-71, Korea.

${ }^{4}$ Laboratory of Fruit Tree Science, University Farm, Faculty of Agriculture, Kyushu University, Fukuoka 811-2307.

+ Corresponding author (E-mail: m-hirama@agr.kyushu-u.ac.jp). 
nation rate of sown seeds from $2 \mathrm{x} \times 4 \mathrm{x}$ and $4 \mathrm{x} \times 2 \mathrm{x}$ crosses was $1.9 \%$ and $2.7 \%$, respectively (Wakana, et al., 2002), indicating seed sowing was not an efficient method for breeding triploid grapes. An another fact that the germination rate of triploid embryos cultured in vitro decreased with decreasing in their size (Wakana et al., 2003) may suggest that in vitro culture at the earlier stages of seed development is necessary for improving efficiency in breeding triploid grapes.

In crosses with stenospermocarpic cultivars as seed parents, seedlings were successfully derived through in ovulo embryo culture with high frequencies (Ramming and Emershad, 1982: Cain et al., 1983; Emershad and Ramming, 1984; Spiegel-Roy et al., 1985; Goldy et al., 1988; Emershad et al., 1989; Gray et al., 1990). Application of same embryo-rescue techniques was also successful in aneuploid production from triploid grapes (Park et al., 1999a) and triploid production from hybridization between diploid and tetraploid grapes (Yamashita et al., 1998). The cases have, however, been very few to date. Thus, further detailed studies on conditions of in vitro techniques should be needed to increase efficiency in breeding triploid and aneuploid grapes.

The purpose of the present study is to clarify 1) effectiveness a combination of immature seed culture and subsequent embryo culture in comparison with sole embryo culture without culturing immature seed, 2) an appropriate seed-development stage for initiation of in vitro culture, 3) effect of abscisic acid, adenine sulfate, gibberellin and indole-3-acetic acid on development of embryos and seedlings, using seeds from artificial interploid crosses between tetraploid and diploid grape.

\section{MATERIALS AND METHODS}

\section{Plant materials and interploid cross}

Diploid cultivar 'Muscat Bailey A' and tetraploid cultivar 'Red Pearl' were used for the interploid cross. They are intercontinental hybrid cultivars (Vitis complex) with Vitis vinifera and North American Vitis species in the pedigrees. Ten- to 15-year-old trees grown in the experimental orchard of University Farm, Kyushu University, Fukuoka were used in the cross. The interploid cross $4 \mathrm{x} \times 2 \mathrm{x}$ was carried out according to the procedure reported previously (Wakana et al., 2002).

\section{Embryo culture without the preceding immature seed culture}

Immature berries set by the artificial hybridization were collected at seven days interval from 49 to 77 days after pollination (DAP). Mature berries collected 120 DAP were also used. The procedure of in vitro embryo culture followed that by Wakana $e$ al. (2003).

\section{A combination of immature seed culture and embryo culture}

Immature berries set by the artificial hybridization were collected $6,12,24$ and 48 $\mathrm{DAP}$, and surface-sterilized for ten minutes in a solution of $1 \% \mathrm{NaClO}$ containing one drop of Tween 20 per liter. After rinsing the immature berries twice in sterilized water, immature seeds were extracted from the berries with forceps and a surgical knife under aseptic conditions. After measuring seed length with a micrometer equipped in a stereoscopic microscope, each immature seed was cultured in a $25 \mathrm{~mm} \times 100 \mathrm{~mm}$ culture glass 
vessel containing autoclaved $10 \mathrm{ml}$ Nitsch and Nitsch (NN) medium (1969) supplemented with $20 \mathrm{~g} / \mathrm{l}$ sucrose and $0.7 \mathrm{~g} / \mathrm{l}$ agar, and adjusted $\mathrm{pH}$ to 5.5 . The culture vessels were placed under continuous light condition $\left(60-80 \mu \mathrm{mol} \mathrm{m}^{-2} \mathrm{~s}^{-1}\right.$, cool-white fluorescent lights) at $25 \pm 2{ }^{\circ} \mathrm{C}$.

To examine independent effect of growth regulators on development of triploid embryos and seedlings, immature seeds collected 52-56 DAP were also cultured by the same procedure, except for supplement of the following regents. The growth regulators supplemented were $1-125 \mathrm{mg} / \mathrm{l}$ adenine sulfate (ADS), $0.01-1.25 \mathrm{mg} / \mathrm{l}$, and indole-3-acetic acid (IAA), 0.01-1.25 mg/ abscisic acid (ABA) and 0.01-1.25 mg/l gibberellin $\left(\mathrm{GA}_{3}\right)$. IAA and $\mathrm{GA}_{3}$ were added to the medium through filtration with sterilized cellulose acetate membrane after autoclaving.

After three months of immature seed culture, length of cultured immature seeds was measured. Embryos inside the seeds were extracted and length of them was measured. Then, the embryos were transplanted into a $200 \mathrm{ml}$ conical flask containing autoclaved $40 \mathrm{ml}$ of Murashige and Skoog (MS) medium (1962) supplemented with $30 \mathrm{~g} / \mathrm{l}$ sucrose, $0.7 \mathrm{~g} / \mathrm{l}$ agar, $500 \mathrm{mg} / \mathrm{l}$ casein hydrolysate and adjusted $\mathrm{pH}$ to 5.7 . Five embryos were planted per flask. Every one of established plantlets was further transplanted into a conical flask containing autoclaved $40 \mathrm{ml}$ MS medium supplemented with $10 \mathrm{~g} / \mathrm{l}$ sucrose, $8 \mathrm{~g} / \mathrm{l}$ agar, $0.01 \mathrm{mg} / \mathrm{l} \mathrm{NAA}, 100 \mathrm{mg} / \mathrm{l}$ casein hydrolysate and adjusted $\mathrm{pH}$ to 5.7 .

\section{RESULTS}

\section{Embryo culture without the preceding immature seed culture}

In the immature seeds collected 49DAP embryos could not be cultured since they were too small to be extracted from the seeds. In berries collected 56, 63, 70, 77 and 120 DAP, $72-85 \%$ of seeds contained embryos (Table 1). Endosperm degeneration was observed in the micropylar half of these seeds. Mean length of the embryos increased from 56 to 77 DAP and the length at 77 DAP reached almost same as that at 120 DAP. Embryos cultured from 56 DAP germinated at the rate of $5.3 \%$, but none of them grew

Table 1. Growth responses of triploid embryos from 'Red Pearl' (4x)×'Muscat Bailey A' (2x) in embryo culture. The embryos were extracted from seeds within immature and mature berries collected 49-120 days after pollination and cultured on Murashige and Skoog (1962) medium. Embryos were not observed at 49 days after pollination.

\begin{tabular}{|c|c|c|c|c|c|c|c|c|}
\hline \multirow[t]{2}{*}{$\begin{array}{l}\text { Days after } \\
\text { pollination } \\
\\
56\end{array}$} & \multirow[t]{2}{*}{$\begin{array}{c}\begin{array}{c}\text { No. of } \\
\text { seeds } \\
\text { examined }\end{array} \\
49\end{array}$} & $\begin{array}{l}\text { No. of seeds } \\
\text { with the } \\
\text { embryo } \\
\text { (\%) }\end{array}$ & \multirow[t]{2}{*}{$\begin{array}{c}\text { Mean length of } \\
\text { embryo at } \\
\text { culture } \\
\text { initiation } \\
\text { (mm) }\end{array}$} & \multirow[t]{2}{*}{$\begin{array}{c}\begin{array}{c}\text { No. of } \\
\text { embryos } \\
\text { cultured }\end{array} \\
38\end{array}$} & \multicolumn{2}{|c|}{$\begin{array}{c}\text { No. of } \\
\text { embryos } \\
\text { germinating } \\
\text { (\% per } \\
\text { cultured } \\
\text { embryo) }\end{array}$} & \multicolumn{2}{|c|}{$\begin{array}{l}\text { No. of } \\
\text { seedlings } \\
\text { established } \\
\text { (\% per } \\
\text { examined } \\
\text { seed) }\end{array}$} \\
\hline & & $40 \quad(81.6)$ & & & 2 & $(5.3)$ & 0 & (0) \\
\hline 63 & 34 & (79.4) & 0.72 & 26 & 3 & (11.5) & 2 & (7.7) \\
\hline 70 & 20 & $17(85.0)$ & 0.83 & 16 & 4 & $(25.0)$ & 1 & (6.3) \\
\hline 77 & 31 & $25 \quad(80.6)$ & 0.98 & 25 & 4 & $(16.0)$ & 2 & $(8.0)$ \\
\hline 120 & 47 & $34 \quad(72.3)$ & 0.93 & 34 & 2 & $(5.9)$ & 2 & $(5.9)$ \\
\hline
\end{tabular}


into plantlets. Embryos cultured from 63,70 and 77 DAP germinated at a relatively high rate (11.5-25.0\%) as compared with those cultured from 120 DAP. The germinating embryos grew into plantlets also at a higher rate $(5.0-6.5 \%$ per seed set) than those cultured from 120 DAP.

\section{A combination of immature seed culture and embryo culture}

Cultured immature seeds turned light green during immature seed culture except that those collected 48 DAP turned brown. In the greening seeds, callus was formed on the outer layers of outer integument. The immature seeds collected 24 DAP were relatively large and grew over the size of mature seeds collected 120 DAP after three months of the culture, whereas those collected 6 and 12 DAP were very small and slightly enlarged after the culture (Table 2). The size of immature seeds collected 48 DAP was nearly same as that of mature seeds collected 120 DAP and slightly enlarged after the culture. None of cultured immature seeds germinated during the culture.

Neither the endosperm nor the embryo was detected in the immature seeds cultured from 6 and 12 DAP (Table 3). For the seeds cultured from 24 and 48 DAP, embryos developed in $45.2 \%$ and $73.1 \%$, respectively. Endosperm development was observed only

Table 2. The in vitro growth of immature seeds extracted from berries at various intervals after pollination in 'Red Pearl' $(4 \mathrm{x}) \times$ 'Muscat Bailey A' (2x).

\begin{tabular}{cccc}
\hline \multirow{2}{*}{$\begin{array}{c}\text { Days after } \\
\text { pollination }\end{array}$} & \multirow{2}{*}{$\begin{array}{c}\text { No. of seeds } \\
\text { examined }\end{array}$} & At the initiation of culture & After three months culture \\
\cline { 3 - 4 } & 25 & 0.94 & 1.10 \\
12 & 20 & 1.90 & 1.62 \\
24 & 31 & 5.17 & 6.85 \\
48 & 26 & 6.04 & 6.22 \\
120 & 47 & 6.08 & $-\mathbf{z}^{2}$ \\
\hline
\end{tabular}

${ }^{\mathrm{z}}$ Mature seeds collected 120 days after pollination were not cultured.

Table 3. Growth response of triploid embryos through immature seed culture and subsequent embryo culture in 'Red Pearl' (4x) X'Muscat Bailey A' (2x). The seeds were extracted from immature berries collected 6-48 days after pollination and cultured for three months on Nitsch and Nitsch (1969) medium.

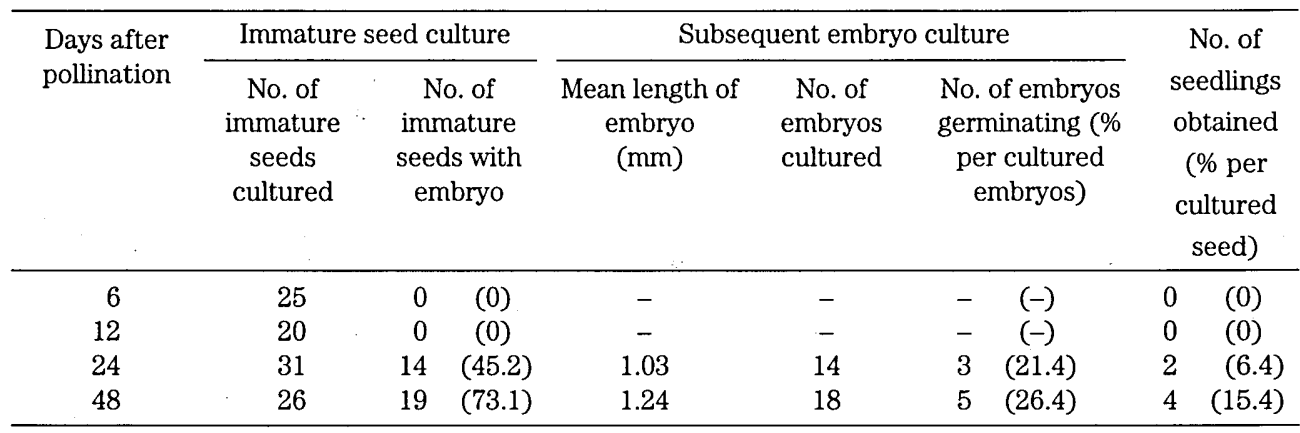


in the latter treatment, though the endosperm development was imperfect and observed only in the micropylar half of the embryo sac as was in the immature seeds beyond 56 DAP. The reached sizes of embryos after culturing immature seeds collected 24 and 48 DAP were larger than that of embryos within mature seeds collected 120 DAP (Table 1 and 3).

After subsequent culture of the embryos developed by immature seed culture, the rate of germination and seedling production both were higher in embryos cultured from $48 \mathrm{DAP}$ than in those from 24 DAP (Table 3). The highest rate of seedling production $(15.4 \%)$ in the successive culture was about 2.4 to 3.6 times as high as the rates in sole embryo culture without the preceding immature seed culture (Table 1 and 3).

\section{Effect of growth regulators}

Addition of four growth regulators on the medium did not show distinct effect on embryo and seedling development in the successive culture (Table 4). It was noticeable that the production rate of seedlings reached $31.5 \%$ without any growth regulators.

Table 4. The effect of growth regulators on growth of triploid embryos in immature seed culture and subsequent embryo culture. The immature seeds were extracted from young berries collected 52-56 days after pollination in 'Red Pearl' $(4 \mathrm{x}) \times$ 'Muscat Bailey A' $(2 \mathrm{x})$ and cultured for three months on Nitsch and Nitsch (1969) medium.

\begin{tabular}{|c|c|c|c|c|c|c|c|c|}
\hline \multirow{2}{*}{$\begin{array}{l}\text { Growth } \\
\text { regulator }\end{array}$} & \multirow{2}{*}{$\begin{array}{c}\text { Concen- } \\
\text { tration } \\
(\mathrm{mg} / \mathrm{l})\end{array}$} & \multicolumn{2}{|c|}{ Immature seed culture } & \multicolumn{3}{|c|}{ Subsequent embryo culture } & \multirow{2}{*}{\multicolumn{2}{|c|}{$\begin{array}{l}\text { No. of } \\
\text { seedlings } \\
\text { established } \\
\text { (\% per } \\
\text { cultured } \\
\text { seed) }\end{array}$}} \\
\hline & & $\begin{array}{l}\text { No. of } \\
\text { immature } \\
\text { seeds } \\
\text { cultured }\end{array}$ & $\begin{array}{l}\text { No. of } \\
\text { immature } \\
\text { seeds with } \\
\text { embryo }\end{array}$ & $\begin{array}{l}\text { Mean } \\
\text { length of } \\
\text { embryo } \\
(\mathrm{mm})\end{array}$ & $\begin{array}{l}\text { No. of } \\
\text { embryos } \\
\text { cultured }\end{array}$ & $\begin{array}{l}\text { No. of } \\
\text { embryos } \\
\text { germi- } \\
\text { nating }\end{array}$ & & \\
\hline Control & 0 & 54 & 48 & 1.15 & 46 & 23 & 17 & $(31.5)$ \\
\hline \multirow[t]{4}{*}{$\mathrm{ADS}$} & 1 & 27 & 21 & 1.21 & 19 & 8 & 7 & $(26.0)$ \\
\hline & 5 & 27 & 24 & 1.16 & 23 & 11 & 6 & $(23.1)$ \\
\hline & 25 & 27 & 23 & 1.17 & 17 & 5 & 3 & (11.1) \\
\hline & 125 & 27 & 22 & 1.27 & 22 & 11 & 6 & $(22.2)$ \\
\hline \multirow[t]{4}{*}{ IAA } & 0.01 & 26 & 23 & 1.12 & 23 & 10 & 7 & $(27.0)$ \\
\hline & 0.05 & 26 & 22 & 1.49 & 21 & 11 & 6 & $(23.1)$ \\
\hline & 0.25 & 26 & 21 & 1.07 & 21 & 11 & 5 & (19.2) \\
\hline & 1.25 & 27 & 24 & 1.34 & 24 & 9 & 5 & (19.2) \\
\hline \multirow[t]{4}{*}{$\mathrm{ABA}$} & 0.01 & 27 & 25 & 1.33 & 24 & 9 & 6 & (22.2) \\
\hline & 0.05 & 27 & 25 & 1.26 & 22 & 6 & 2 & $(7.4)$ \\
\hline & 0.25 & 27 & 27 & 1.03 & 23 & 11 & 5 & (18.5) \\
\hline & 1.25 & 27 & 23 & 1.25 & 22 & 4 & 2 & $(22.2)$ \\
\hline \multirow[t]{4}{*}{ GA } & 0.01 & 28 & 25 & 1.26 & 23 & 9 & 6 & (21.4) \\
\hline & 0.05 & 27 & 23 & 1.10 & 19 & 9 & 5 & (18.5) \\
\hline & 0.25 & 26 & 23 & 1.30 & 22 & 9 & 6 & (23.1) \\
\hline & 1.25 & 27 & 25 & 1.41 & 24 & 9 & 7 & $(26.0)$ \\
\hline
\end{tabular}




\section{DISCUSSION}

Comparison of a series of our studies on triploid production from $4 \mathrm{x}$ 'Red Pearl' $\times 2 \mathrm{x}$ 'Muscat Bailey A' by in vitro techniques and sowing seeds shows that a combination of immature seed culture and subsequent embryo culture is the most efficient method (Table 5). Combined with results from similar study using triploid grapes by Yamashita et al. (1998) and aneuploid grapes by Parks et al. (1999a), our results show that the combination culture of immature seeds and embryos extracted from them could be widely applicable to most interploid crosses using diploid, tetraploid and triploid grapes.

The fact that immature seeds collected 48 to 56 DAP were superior in seedling recovery to those collected before $24 \mathrm{DAP}$ indicates that the effective period initiating the immature seed culture is one or two weeks before the beginning of fruit-softening period, namely 'varaison'. In the very early stage of seed development, the tissues inside the seeds such as nucellus and endosperm are supposed to lack the ability of nutritional supply to the immature embryos because of the high degree of their underdevelopment or degeneration.

The sole in vitro culture of embryos extracted from immature seeds collected 63-77 DAP showed rather higher recovery rates than that extracted from mature seeds collected 120 DAP. The fact indicates that embryos of immature seeds beyond the veraison stage remained more viable than those of mature seeds. In many cases of the culture, however, embryos smaller than $1 \mathrm{~mm}$ ceased the growth and could not germinate (see also Wakana et al., 2003). The more immature embryos cultured from 56 DAP were, furthermore, very difficult to grow. These results demonstrate that many of the underdeveloped triploid embryos themselves are supposed to be highly heterotrophic, and impossible to grow further only by supplying artificial nutrients. It is, thus, stressed again that co-cultured nuceller and endosperm tissues are very critical for promoting growth of immature triploid embryos as sources of effective nutritional supply.

The reason why the four growth regulators used in the present study were not effective for the development of immature seeds and the embryos within them is obscure. Addition of these growth regulators on culture media have been reported to be effective for the recovery of hybrid seedlings from crosses with stenospermocarpic grapes through

Table 5. Compariosn of the rates of seedling recovery by in vitro techniques and seed sowing in $4 \mathrm{x}$ 'Red Pearl' $\times 2 \mathrm{x}$ 'Muscat Bailey A' among our recent and the present studies.

\begin{tabular}{llcc}
\hline Method & $\begin{array}{l}\text { Stage of berry } \\
\text { development }\end{array}$ & $\begin{array}{c}\text { The optimum time for } \\
\text { seed collection } \\
\text { (days after } \\
\text { pollination) }\end{array}$ & $\begin{array}{c}\text { \% of seedlings } \\
\text { established per } \\
\text { setting or cultured } \\
\text { seed }\end{array}$ \\
\hline $\begin{array}{l}\text { Sowing seed } \\
\text { Embryo culture }\end{array}$ & Mature & $>90$ & 0 \\
Embryo culture & Mature & $>90$ & 5 \\
Immature seed culture & Veraison & $60-80$ & 7 \\
\hline
\end{tabular}

${ }^{\mathrm{z} W a k a n a}$ et al., 2002; ' Wakana et al., 2003. 
in ovulo embryo culture (Spiegel-Roy et al., 1985; Gray et al., 1990; Tsolova, 1990). The difference in the effect of the growth regulators among the studies might be attributed to the genetic and physiological difference in functions of nutritional supply of the underdeveloped endosperm and nucellus.

\section{REFERENCES}

Cain, D. W., R. L. Emershad and R. E. Tarailo 1983 In ovulo embryo culture and seedling development of seeded and seedless grapes (Vitis vinifera L.). Vitis, 22: 9-14

Einset, J. and C. Pratt 1975 Grape. In "Advances in fruit breeding", ed. by J. Janick and J. N. Moore, Purdue Univ. Press, West Lafayette, pp. 130-153

Esen, A. and R. K. Soost 1973 Seed development in Citrus with special reference to $2 \mathrm{x} \times 4 \mathrm{x}$ crosses. Amer. J. Bot., 60: 448-462

Emershad, R. L. and D. W. Ramming 1984 In ovulo embryo culture of Vitis vinifera L. c.v. 'Thompson Seedless'. Amer. J. Bot., 71: 873-877

Emershad, R. L., D. W. Ramming and M. D. Serpe 1989 In ovulo embryo development and plant formation from stenospermic genotypes of Vitis vinifera. Amer. J. Bot., 76: 397-402

Goldy, R. R., R. L. Emershad, D. W. Ramming and J. Chaparro 1988 Embryo culture as a means of introgressing seedlessness from Vitis vinifera to Vitis rotundifolia. Hort. Sci., 23: 886-869

Gray, D. J., J. A. Mortensen, C. M. Benton, R. E. Durham and G. A. Moore 1990 Ovule culture to obtain progeny from hybrid seedless bunch grapes. J. Amer. Soc. Hort. Sci., 115: 1019-1024

Mullins, M. G., A. Bouquet and L. E. Williams 1992 Biology of the grapevine. Cambridge Univ. Press, Cambridge

Murashige, T. and F. Skoog 1962 A revised medium for rapid growth and bioassays with tobacco tissue cultures. Physiol. Plant., 15: 473-497

Nitsch, J. P. and C. Nitsch 1969 Haploid plants from pollen grains. Science, 163: 85-87

Park, S. M., M. Hiramatsu and A. Wakana 1999a Aneuploid plants derived from crosses with triploid grapes through immature seed culture and subsequent embryo culture. Plant Cell, Tissue and Organ Culture, 59: 125-133

Park, S. M., A. Wakana and M. Hiramatsu 1999b Most hypotetraploid seedlings from self-pollinated tetraploid grapes (Vitis complexes) have abnormal cotyledons. J. Fac. Agr., Kyushu Univ., 46: 281-294

Park, S. M., A. Wakana, J. H. Kim and C. S. Jeong 2002 Male and female fertility in triploid grapes (Vitis complex) with special reference to the production of aneuploid plants. Vitis, 41: 11-19

Ramming, D. W. and R. L. Emershad 1982 In ovulo embryo culture of seeded and seedless Vitis vinifera L. HortScience., 17: 487

Sanford, J. G. 1983 Ploidy manipulations. In "Methods in fruit breeding", ed. by N. Moore and J. Janick, Purdue Univ. Press, West Lafayette, pp. 100-123

Spiegel-Roy, P., P. Sahar, J. Baron and U. Lavi 1985 In vitro culture and plant formation from grape cultivars with abortive ovules and seeds. J. Amer. Soc. Hort. Sci., 110: 109-112

Tsolova, V. 1990 Obtaining plants from crosses of seedless grapevine varieties by means of in vitro embryo culture. Vitis, 29: 1-4

Wakana, A., M. Hiramatsu, S. M. Park, H. Hanada, I. Fukudoe and B. X. Ngo 2002 Degree of abortion and germination rates in triploid seeds from crosses between diploid and tetraploid grapes (Vitis vinifera L. and V. complex). J. Fac. Agr., Kyushu Univ., 46: 281-294

Wakana, A., M. Hiramatsu, S. M. Park, N. Hanada, I. Fukudome and K. Yasukochi Seed abortion in crosses between diploid and tetraploid grapes (Vitis vinifera and V. complex) and recovery of triploid plants through embryo culture. J. Fac. Agr., Kyushu Univ., 48: 39-50

Winkler, A. J., J. A. Cook, W. M. Kliewer and L. A. Lider 1962 General viticulture. California Univ. Press, Berkley

Yamashita, H., I. Shigehara and T. Hanuda 1998 Production of triploid grapes by in ovulo embryo culture. Vitis, 37: 113-117 